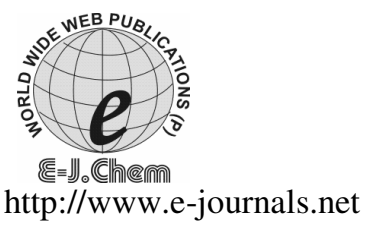

\title{
Studies on Novel Bisaryl hydrazino-s-triazine Derivatives
}

\author{
${ }^{1}$ J.A.CHAUDHARI* ${ }^{2}{ }^{2}$ M.V.HATHI and ${ }^{3}$ R.P.PATEL \\ ${ }^{1}$ Shri R.K.Parikh Arts \& Science College, Petlad-388450. GUJARAT \\ ${ }^{2}$ R.R.Mehta College of Sci.\& C.L.Parikh college of Commerce \\ Palanpur-385001. GUJARAT \\ ${ }^{3}$ C.U.Shah Science College, Ahmedabad-380014. GUJARAT. India
}

Received 14 July 2006; Accepted 22 August 2006

\begin{abstract}
Various 2-phenyloxy-4,6-bisarylhydrazino-1,3,5-triazines(3a-f) were prepared by reaction of 2- phenyloxy -4,6-dichloro -1,3,5-triazine and various aryl hydrazine derivatives. All the $3 \mathrm{a}-\mathrm{f}$ derivatives were characterized by elemental analysis and IR spectral studies. All the compounds were screened for microbial activity against gram-positive and gram-negative bacteria.
\end{abstract}

Keywords: Phenyloxy bisaryl hydrazino s-triazine derivatives, hydrazines, IR \& spectral study, antimicrobial activity.

\section{Introduction}

Number of derivatives containing s-triazine ring have been reported as hetrocyclic compounds ${ }^{1}$. They are applicable mostly as reactive dyes and some are used as polymers and drugs ${ }^{2,3}$. The aryl hydrazine derivatives containing s-triazine ring are not reported so far except one instance ${ }^{4}$. Recently our university scientists have studied the hydrazine triazine clubbed molecules having alkoxy group ${ }^{4}$. Hence in continuous of this work ${ }^{4}$, the two of the authors(RPP,MVH) have reported the aryl hydrazine derivatives of based on 2-phenyloxy4,6-dichloro $-1,3,5$-triazine ${ }^{5}$. In continuous of this work ${ }^{5}$ and the reports about the heterocyclic s-triazine derivatives ${ }^{2-4}$ the present paper comprises the work shown in Scheme-1. 


\section{Experimental}

\section{Materials}

Cyanuric chloride and all the aryl hydrazine derivatives(substitution shown in Scheme-1 were obtained as Analar grade from local dealer.2- phenyloxy -4,6-dichloro -1,3,5-triazine was prepared by reported method ${ }^{4}$. All other chemicals used were of laboratory grade.

\section{Synthesis of bisaryl hydrazino-s-triazines}

2-phenyloxy-4,6-bisaryl hydrazino-1,3,5-triazines (3a-f). The general procedure for these compounds is as follows.

To a well stirred solution of 2- phenyloxy -4,6-dichloro-1,3,5-triazine (0.01 mole) in tetrahydrofuran (THF) solvent $(50 \mathrm{ml})$ a solution of aryl hydrazine (or substituted aryl hydrazine) (scheme-1) (0.02mole) in THF $(50 \mathrm{ml})$ was added gradually at room temperature. The mixture was stirred for two hours. Then the mixture was refluxed for further two hours. The resultant solid product was filtered, washed with THF and air-dried. All the (3a-f) compounds listed in Table-1 are dark yellow amorphous powders. Their melting points shown in Table-1 and they are uncorrected.

\section{Structure - 1}

\section{Characterization of 2-Phenyloxy -4,6- bisaryl hydrazino -1,3,5-triazine (3a-f)}

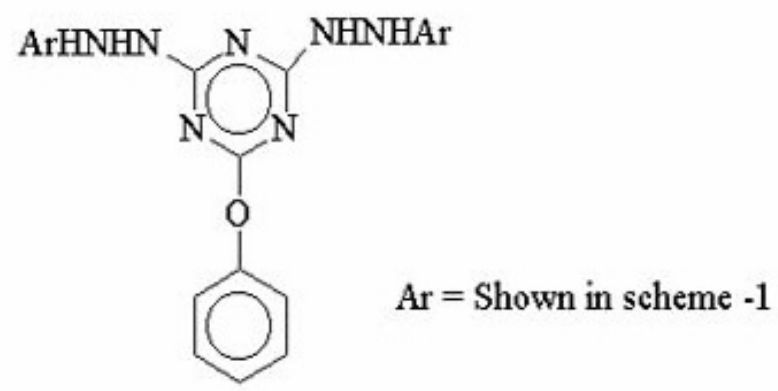

Table 1

\begin{tabular}{|c|c|c|c|c|c|c|c|c|}
\hline \multirow{2}{*}{ Compound } & \multirow{2}{*}{$\begin{array}{l}\text { Molecular } \\
\text { Formula }\end{array}$} & \multirow{2}{*}{$\begin{array}{c}\text { Mol. } \\
\text { Weight }\end{array}$} & \multicolumn{2}{|c|}{$\% \mathrm{C}$} & \multicolumn{2}{|c|}{$\% \mathrm{H}$} & \multicolumn{2}{|c|}{$\% \mathrm{~N}$} \\
\hline & & & Cald. & Found & Cald & Found & Cald. & Found \\
\hline $3-a$ & $\mathrm{C}_{21} \mathrm{H}_{19} \mathrm{~N}_{7} \mathrm{O}$ & 385 & 65.45 & 65.4 & 4.93 & 4.8 & 25.45 & 25.4 \\
\hline $3-b$ & $\mathrm{C}_{21} \mathrm{H}_{17} \mathrm{~N}_{7} \mathrm{Cl}_{2} \mathrm{O}$ & 454 & 55.51 & 55.4 & 3.74 & 3.6 & 21.59 & 21.5 \\
\hline $3-c$ & $\mathrm{C}_{21} \mathrm{H}_{17} \mathrm{~N}_{7} \mathrm{Br}_{2} \mathrm{O}$ & 543 & 46.41 & 46.3 & 3.13 & 3.0 & 18.05 & 18.0 \\
\hline $3-d$ & $\mathrm{C}_{23} \mathrm{H}_{23} \mathrm{~N}_{7} \mathrm{O}$ & 413 & 66.83 & 66.7 & 5.57 & 5.5 & 23.73 & 23.6 \\
\hline $3-\mathrm{e}$ & $\mathrm{C}_{23} \mathrm{H}_{23} \mathrm{~N}_{7} \mathrm{O}_{3}$ & 445 & 62.02 & 61.9 & 5.17 & 5.0 & 22.02 & 21.9 \\
\hline $3-\mathrm{f}$ & $\mathrm{C}_{21} \mathrm{H}_{17} \mathrm{~N}_{9} \mathrm{O}_{5}$ & 475 & 53.05 & 52.9 & 3.58 & 3.5 & 26.53 & 26.4 \\
\hline
\end{tabular}


Scheme-1<smiles>Clc1nc(Cl)nc(Cl)n1</smiles>

Cyanuric chloride<smiles>Oc1ccccc1</smiles>

Sodiam phenoxide

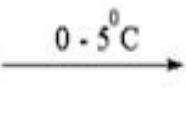<smiles>Oc1nc(Cl)nc(Cl)n1</smiles><smiles>Oc1ccccc1</smiles>

2-Phenyloxy dichloro-1,3,5-triazine

$$
\mid \begin{gathered}
\text { Aryl hydrazine(Excess) } \\
+ \\
\mathrm{K}_{2} \mathrm{CO}_{3} \\
\text { (Room temp.) }
\end{gathered}
$$
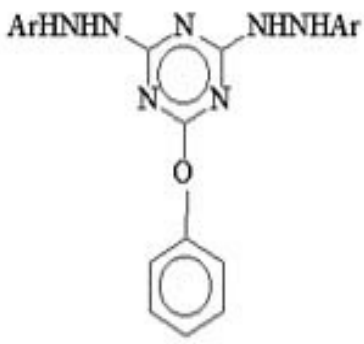

2-Phenyloxy bisaryl hydrazino-1,3,5-triazine $(3 a-f)$

Where, $\mathrm{ArNHNH}_{2}$

a:<smiles>Cc1ccc(NN)cc1</smiles>

b:<smiles>CC(=O)c1ccc(NN)cc1</smiles>

c:<smiles>NNc1ccc(N=O)cc1</smiles> 


\section{Mesurements}

The elemental analysis of all (3a-f) compounds were determined by TF flash EA. The FT-IR spectra of (3a-f) compounds were scanned in $\mathrm{KBr}$ pallets on Perkin Elmer FT-IR spectrophotometer. The NMR spectra of soluble sample No.3e was scanned on Perkin Elmer FT-NMR spectrophotometer.

\section{Antimicrobial Activity}

For the testing antimicrobial activity various microorganism were used for the study. The pour plate agar method was used for this study. Following general procedure is adopted ${ }^{7}$. The antimicrobial activity of all the compounds was studies at $1000 \mathrm{ppm}$ concentration in vitro. The different types of microorganism used were some gram negative bacteria [Escherichia coli,Proteus valgaris], gram positive bacteria [Bacillus cereus, Streptococus species], fungi [Aspergillus oryzac], yeast [Pichia species] and actinomycetes [Streptomyces coleicor].

The antibacterial activity of 3a-f compounds was measured on each of these microorganism strains on a potato dextrose agar medium (PDA). Such a PDA medium contained ${ }^{5}$ potato 200 gram, dextrose 20 gram, agar 30 gram, and water 1 Litre. PDA medium autoclaved at $121^{\circ} \mathrm{C}$ temperature and $15 \mathrm{lbs}$ pressure for 15 minute. After autoclaving the compounds to be tested were inoculated $(1000 \mathrm{ppm})$ in PDA medium at $42^{\circ} \mathrm{C}$ temperature and mix it than these media were poured in to sterile empty glass petriplates. The testing microorganism [young culture] were inoculating after solidification of the PDA medium plates. The percentage inhibition of growth of microorganism was calculated after 5 days of incubation of PDA medium plate inoculated with microorganism at appropriate temperature [Bacteria- $37^{\circ} \mathrm{C}$, Fungi- $25^{\circ} \mathrm{C}$, Actinomyces- room temp.] percentage of inhibition of microorganism was calculated by using the formula given below.

Percentage of inhibition of growth of microorganism $=\frac{100(\mathrm{X}-\mathrm{Y})}{\mathrm{X}}$

Where, $X=$ area of bacterial growth in control plate $(\mathrm{mm})$,

$\mathrm{Y}=$ area of bacterial growth in test plate $(\mathrm{mm})$.

The antimicrobial activity of all the 3a-f compounds are furnished in Table-2

Table 2. Antimicrobial activity of 2 -Phenyloxy -4,6- bisaryl hydrazino -1,3,5- triazines (3a to $f)$

\begin{tabular}{|c|c|c|c|c|c|c|c|}
\hline \multirow[b]{2}{*}{ Sample } & \multicolumn{7}{|c|}{ Percentage of inhibition of growth at $1000 \mathrm{ppm} \mathrm{( \% )} \mathrm{concentrate} \mathrm{of} \mathrm{sample}$} \\
\hline & $\begin{array}{c}\text { Bacillus } \\
\text { cereus }\end{array}$ & $\begin{array}{c}\text { Streptococcus } \\
\text { species }\end{array}$ & $\begin{array}{c}\text { Escherichia } \\
\text { coli }\end{array}$ & $\begin{array}{l}\text { Proteus } \\
\text { vulgaris }\end{array}$ & $\begin{array}{c}\text { Aspergillus } \\
\text { oryzac }\end{array}$ & $\begin{array}{l}\text { Pichia } \\
\text { species }\end{array}$ & $\begin{array}{c}\text { Streptomyces } \\
\text { coleicolor }\end{array}$ \\
\hline Control & Nil & Nil & Nil & Nil & Nil & Nil & Nil \\
\hline 3-a & 65 & 95 & 80 & 80 & 65 & 69 & 60 \\
\hline $3-b$ & 100 & 98 & 97 & 96 & 98 & 97 & 95 \\
\hline $3-\mathrm{c}$ & 71 & 91 & 100 & 78 & 65 & 71 & 60 \\
\hline $3-d$ & 73 & 85 & 72 & 55 & 62 & 69 & 60 \\
\hline $3-\mathrm{e}$ & 86 & 85 & 95 & 68 & 60 & 68 & 65 \\
\hline $3-f$ & 69 & 69 & 99 & 62 & 65 & 66 & 59 \\
\hline
\end{tabular}




\section{Results and Discussion}

The reaction beween aryl hydrazine and 2-phenyloxy-4,6-dichloro-1,3,5-triazine is facile. The products (3a-f) are dark yellow amorphous powders. The $\mathrm{C}, \mathrm{H}, \mathrm{N}$ contents of all (3a-f) shown in Table-1 are consistent with the predicated structures shown in Scheme-1. the IR spectra of all (3a-f) are almost identical. All the IR spectra comprises following important features.
1. -NH-NH- (hydrazine group) : $3280,1610,820 \mathrm{~cm}^{-1}$
2. s-triazine $: 1510,1250,870 \mathrm{~cm}^{-1}$
3. -NH- (secondary) $: 3400 \mathrm{~cm}^{-1}$
4. Aryl-O-Aryl : $: 1200 \mathrm{~cm}^{-1}$

As the compounds (3a-f) except $3 \mathrm{e}$ are insoluble $\mathrm{CDCl}_{3}$, the NMR spectral study attempted for $3 \mathrm{e}$. The NMR spectrum of $3 \mathrm{e}$ comprises the multiplate between 6.9 to $8.1 \delta$ ppm mainly due to aromatic protons. While the signal at $2.6 \delta \mathrm{ppm}$ with integration of $6 \mathrm{H}$ is responsible for two $\mathrm{CH}_{3}$ of $\mathrm{OCH}_{3}$ groups. The signals in most downfield $(9.5 \delta \mathrm{ppm})$ is from NH-NH protons. The result of anti microbial screening showed (Table-2) that compounds $3 \mathrm{~b}, \mathrm{c}, \mathrm{f}$ displayed a high order of antibacterial activity and remaining compounds showed weak to moderate activity against both the bacteria. Similarly compounds $3 \mathrm{a}, \mathrm{d}$, and e showed higher antifungal activity and remaining compounds displayed moderate antifungal activity against both the fungi.

\section{Conclusion}

The synthesis of arylhydrazino -s-triazine is facile. The produced compounds have good microbial toxicity. Due to NH-NH groups these compounds can be utilized for epoxy resin hardner. Such work in polymer journal will be published shortly.

\section{Acknoledgements}

Thanks to Dr.M.V.Hathi, honorary scientist science college, Palanpur, North Gujarat, for permission to extend his work. The authors are also grateful to Dr.N.S.Mistry for carry out antimicrobial acticity. One of the author (JAC) is also thankful to Jupiter dye chem. Vapi for carry out research work. Also grateful to the principal Dr.Vimal S Joshi for permission to carry out the research work.

\section{Reference}

1. Sherman S, Ganon J, Buchi G, Howell K O and Eneyel W R, Chem. Tech. Epoxy Resins, Jhon Wiley and Inc. New York, 1980, 9, 267.

2. Freeman H S and Esancy J F, Colour Chemistry, Elsevir, London and New York 1991.

3. Smolin E M and Rapopret L, S-Triazine and derivatives interscience New York, 1954.

4. Patel B R, Patel A M and Patel G A, Oriental J. Chem 2001, 17(3) 523.

5. Seekey H W and Denmark P J, Microbes in action: A laboratory material of microbiology $2^{\text {nd }}$ ed.; Taraporwala Sons Pvt. Ltd, Bombay 1975.

6. Faguda T, Avdv. Exptl. Pathol. Pharmakol 1932 164, 585.

7. Barry A L, The antimicrobial susceptibility test, Principle and practies, $4^{\text {th }}$ ed. Philandelphia, 1976, pp 180-193. 


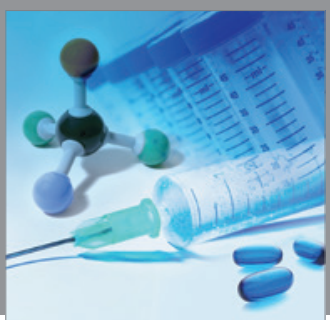

International Journal of

Medicinal Chemistry

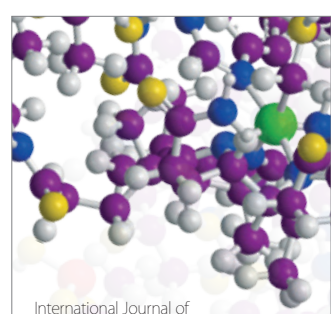

Carbohydrate Chemistry

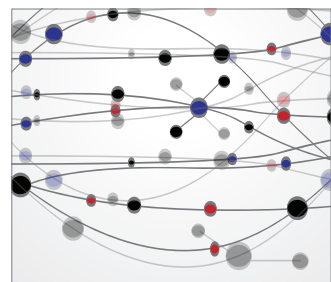

The Scientific World Journal
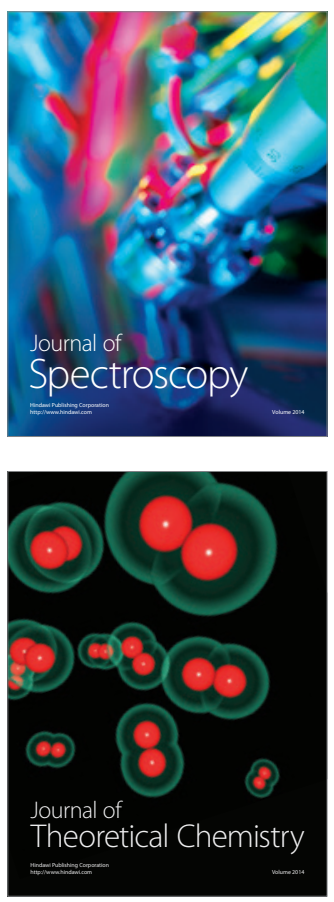
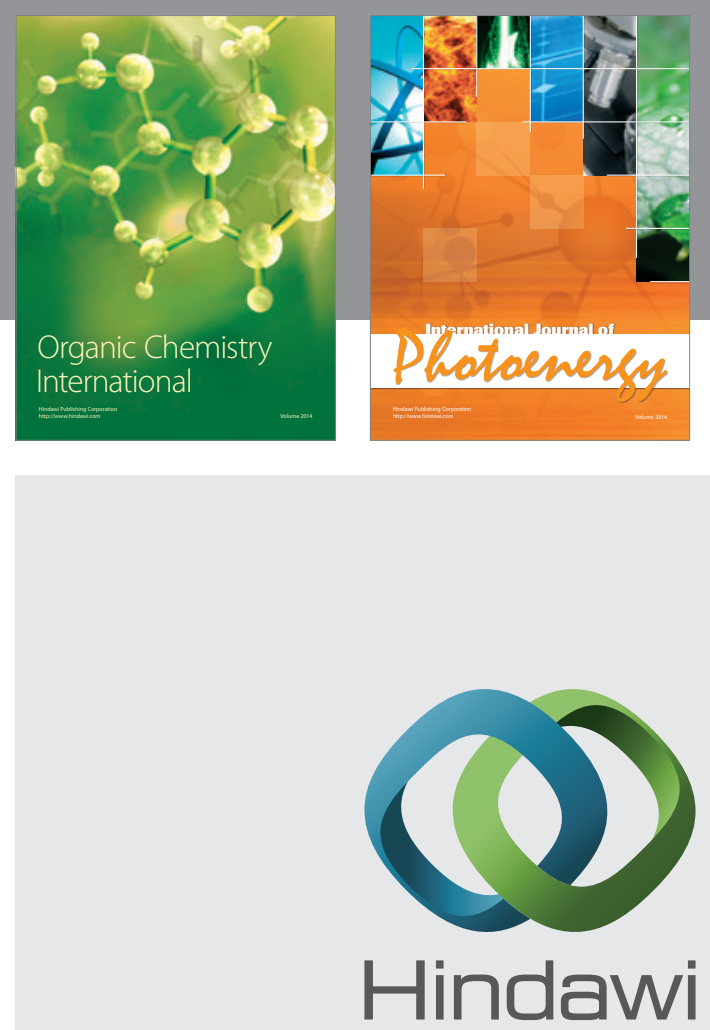

Submit your manuscripts at

http://www.hindawi.com
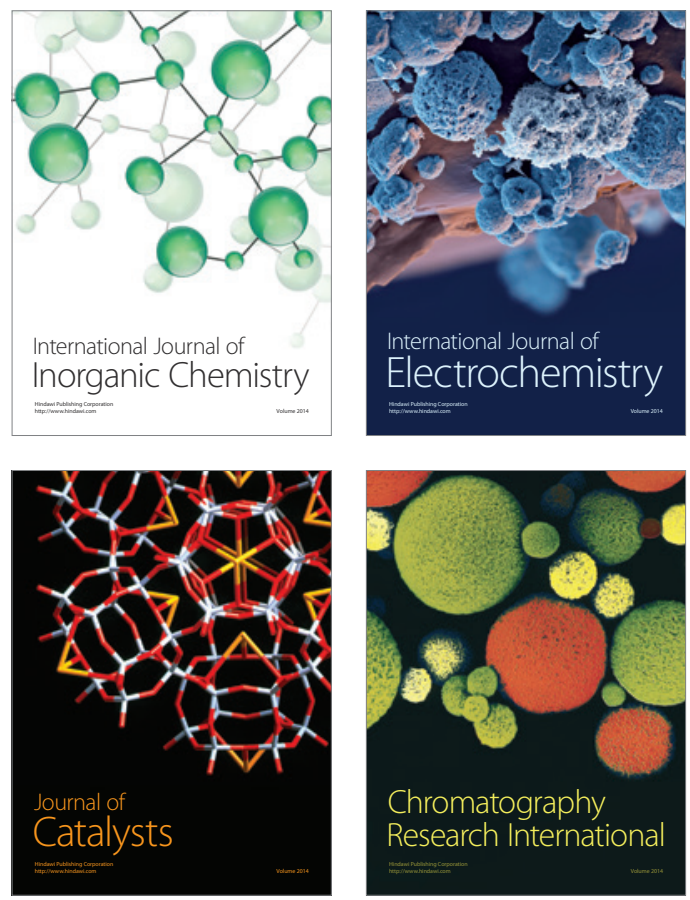
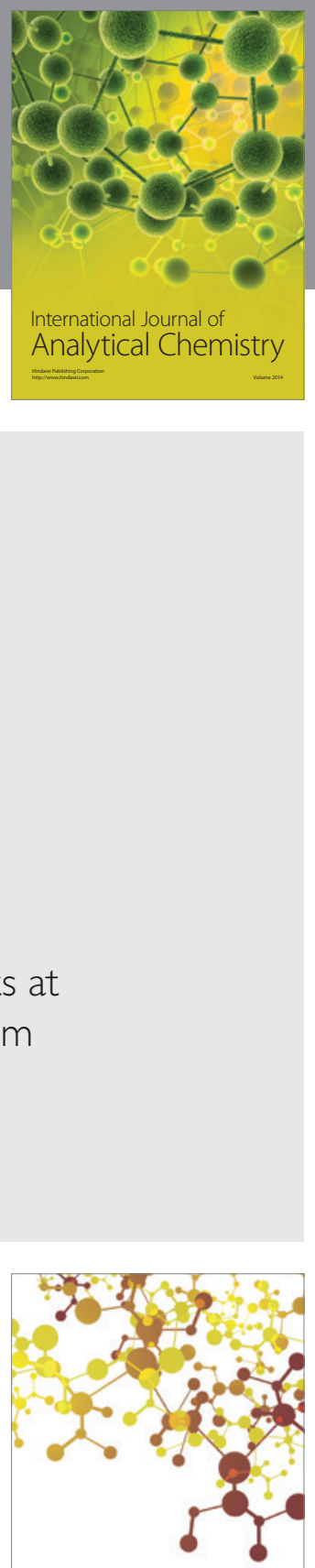

Journal of

Applied Chemistry
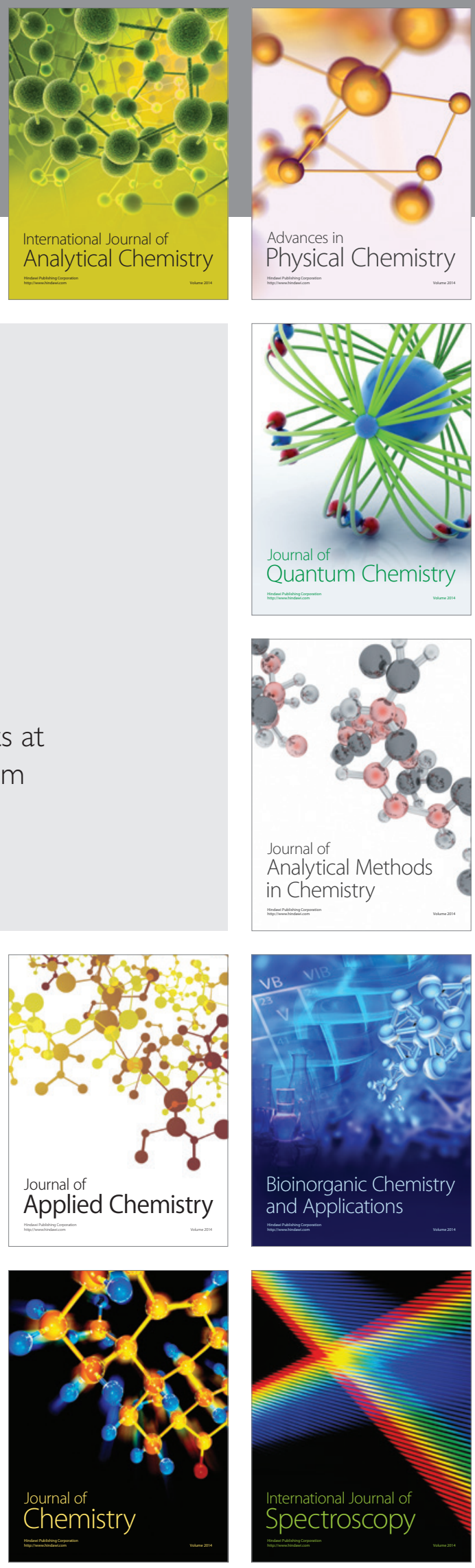